\title{
Reflexe a její podoba v procesu učení a osobnostně sociálním rozvoji ${ }^{1}$
}

\author{
Reflection and its Form in Learning Process and Personal-Social Development \\ Jan Nehyba, Jan Kolář, Martin Hak
}

\begin{abstract}
Abstrakt: Tento příspěvek pojednává o problematice reflexe a jejím významu ve zkušenostně reflektivním učení. Nabízí stručný přehled několika vzdělávacích konceptů využívajících reflexi a poukazuje na jejich společný základ. Teoretické vymezení problematiky v závěru obohacujeme o data shromážděná $v$ rámci pilotního empirického šetření sledujícího podobu vedení reflexe v bezprostřední pedagogické realitě.
\end{abstract}

Klíčová slova: reflexe, zkušenostně reflektivní učení, pilotní šetření

\begin{abstract}
This paper discusses problems of reflection and its meaning in reflective experiential learning. It deals with a brief description of several educational concepts using reflection and points to their common base. We enrich the theoretical definition of the issue with the data collected in the pilotage empirical investigation pursuing the form of reflection in the form of immediate pedagogical reality.
\end{abstract}

Keywords: reflection, experiential reflective learning, a pilot survey

\section{1 Úvod}

Reflexe je v současné době velmi frekventovaným pojmem, jenž se v souvislosti s kontextem jeho použití objevuje $\mathrm{v}$ mnoha různých konotacích. V překládaném článku budeme reflexi nahlížet zejména optikou konceptu zkušenostně reflektivního učení ${ }^{2}$. V první části nejprve poukážeme na roli, kterou reflexe $\mathrm{v}$ rámci tohoto přístupu $\mathrm{k}$ učení a několika historicky vzniklých pojetí zaujímá. Následující druhou část posléze věnujeme analýze provedené empirické sondy, prostřednictvím níž jsme jednu z možných podob reflexe sledovali v bezprostřední praxi.

\section{Reflexe ve zkušenostně reflektivním učení}

Sledujeme-li historii pojmu reflexe jako významné složky učení, nelze opomenout především Deweye, který ve svém pojetí považuje reflexi za obecný př́stup ke zkoumání reality okolního světa. Reflexe pro něj představuje „ohlédnutí se zpět pres to, co se stalo, tak aby byla extrahována sit' významü, která je základním kapitálem inteligentního jednání pro dalši zkušenosti“ (Dewey, 1938, s. 110).

\footnotetext{
${ }^{1}$ Text př́spěvku vznikl v souvislosti s realizací projektů Zkušenostní učení pro praxi - podpora odborné př́pravy stávajicich/budoucich učitelů (reg. číslo CZ.1.07/2.2.00/18.0004) financovaného Evropskou unií a státním rozpočtem České republiky a Škola: výzkum vnitřnich procesů a vnějších podmínek jejího fungování (GA406/09/H040) financovaného Grantovou agenturou České republiky.

${ }^{2}$ Více o důvodech používání tohoto pojmu viz Nehyba (2011).
} 
Odraz reflektivního uvažování tohoto autora lze spatřit také v Lewinově akčním výzkumu (1946), který byl mimo jiné napojen na dobový proud myšlení ovlivněný postupně se rodícím paradigmatem kybernetiky. Její přední představitel Bateson (1972) již v roce 1951 pojednává o různých úrovních učení, jež se staly inspirací také pro Argyrise, který společně se Schönem (1974) aplikuje myšlenku reflektivního uvažování do konceptu organizačního učení.

Poslední zmíněný autor pak přichází v roce 1983 s konceptem reflektivní praxe (srov. Schön, 2003). Ten se stal důležitým modelem propojujícím teorii a praxi např́íc mnoha vědními obory. K současným autorům, kteří dále rozvíjeli myšlenky reflektivní praxe, patří rovněž např. Mezirow (1990) a Thompson (2008).

Koncept zkušenostního učení je naopak dobře známý především z prací Kolba (1984; Kolb, Fry, 1975) odkazujícího se nejen na již zmiňovaného Deweye a Lewina, ale rovněž také na Piagetovu teorii kognitivního vývoje.

Všechny tyto teorie získaly postupem času na velké oblibě, stejně tak se však objevila i celá řada zcela nových konceptů, které se snaží platformu zkušenostně reflektivního učení sumarizovat či dále obohatit. Nejčastěji jsou tato pojetí předkládána v podobě různorodých cyklů učení rozložených okolo centrálních kategorií, a to zážitku či zkušenosti a jejich následného zpracování - reflexe. Krom zmiňovaného Kolba uved'me v této souvislosti např. Priesta a Gasse (2005), kteří sledují kontext edukace v prírodě, nebo Jarvise (1995) zaměřujícího se především na oblast vzdělávání dospělých.

V odborné literatuře se také často objevuje Deweyův či Lewinův model zkušenostního učení. V tomto ohledu je však nutné zdůraznit, že jde o iniciativu samotného Kolba (1984), který se tímto způsobem pokusil interpretovat jejich dílo a zcelit poznatky o zkušenostním učení těchto autorů. Vedle zkušenostně reflektivních cyklů nacházíme ovšem také pouze čistě reflektivní modely učení (např. Boud, Keogh, Walker, 1985; Gibbs, 1988).

Pro jasnější představu o struktuře procesu reflexe uved'me např. Gibbsovo schéma modelu reflexe zahrnující:

- Popis situace (Co se stalo?);

- obrat k pocitům (Jaké pocity a myšlenky při dané aktivitě jsem prožíval?);

- hodnocení (Co dobrého a špatného si z této situace mohu vzít?);

- analýzu (Jaký smysl tato situace může mít?);

- závěr (Co dalšího mohu udělat?);

- akční plán (Pokud se dostanu do této situace znovu, co udělám jinak?).

Jak je patrné, existuje velmi mnoho teoretických modelů znázorňujících zkušenostní nebo reflektivní cykly učení, a to včetně postupů či návodů k možnému využití v praxi. Z důvodu omezené délky textu však nebudeme jednotlivé teorie a pojetí podrobněji popisovat. Odkazujeme proto pouze na odborné zdroje, které jsou v české odborné literatuře v různých souvislostech opakovaně zmiňované.

Na tomto místě je nicméně třeba položit si otázku: „Daří se tyto postupy, resp. zásady zkušenostně reflektivního učení v praxi naplňovat?“" „Jakou podobu mají reflexe v bezprostřední pedagogické realitě a jakým způsobem je ovlivňuje osoba facilitátora ? ? Je možné tento proces sledovat? Vedeni těmito otázkami jsme se rozhodli realizovat empirickou sondu.

\footnotetext{
${ }^{3}$ Pro účely článku jej chápeme jako lektora, jenž podporuje, usměrňuje, popřípadě řídí průběh reflektivního procesu.
} 


\section{Výsledky empirické sondy}

Cílem našeho spíše subtilního empirického šetření bylo mj. také ověřit, zda lze výše nastíněné téma vůbec empiricky uchopit a zda je pozorování facilitace reflexe (resp. práce facilitátora) validním výzkumným nástrojem. $Z$ tohoto důvodu jsme provedli analýzu audiovizuálního záznamu průběhu skupinové reflexe vedené facilitátorem, jenž se zabývá oblastí osobnostně sociálního rozvoje dospělých. Záznam zachycuje v terminologii Schöna „,reflexi po akci“, tedy analýzu situace ex-post. Sledovanou situací byla závěrečná reflexe osmidenního sebezkušenostního kurzu zaměřeného na teoreticko-metodickou prŕípravu hlavních vedoucích dětských skautských táborů. Cílem reflexe bylo shrnutí významných událostí kurzu a jejich „vytěžení“ s ohledem na využití získaných znalostí, dovedností a hodnot v reálném (,„pokurzovém“) životě. Získaná data byla analyzována na základě principů otevřeného kódování, tedy prostřednictvím identifikace spolu souvisejících významových celků a jejich následného pojmenovávání (Strauss, Corbinová, 1999).

Reflexe je individuální proces učení. Zkoumáme-li tedy pojetí reflexe lektora, zkoumáme to, jak facilitátor k tomuto procesu přistupuje, jak se jej snaží ovlivňovat, řídit, popř. usnadňovat.

První úsek, který lze ze záznamu vypozorovat je „naladění na skupinu“. Tato fáze spočívá v zapojení facilitátora do nezávazné komunikace jednotlivých členů před zahájením vlastní reflexe, tedy např. v době než se všichni účastníci dostaví, usadí apod. Navazuje kontakt a přebírá iniciativu v komunikaci a pozornost směřuje na sebe tak, aby si připravil půdu pro další ř́zení aktivity. [facilitátor]: Můžeš si tam sednout, nebo, B., když si sedneš tady, tak budeš aspoň na objektivu. [zvoní telefon] [účastnik]: Nazdar G. [facilitátor]: Pozdravujeme $G \ldots$. Z ukázky je zřejmá lektorova snaha eliminovat a zužitkovat vlivy, které by mohly negativně ovlivnit budoucí proces reflexe, takovým způsobem, aby skupina nebyla ničím rozptylována. Lektor tímto způsobem zajišt'uje sám sobě i účastníkům reflexe bezpečný prostor. Pozornost si jistě zaslouží i sémantická rovina jednotlivých interakcí - např̀. do jaké míry a především k jakým účelům a s jakým efektem facilitátor využívá humor, ironii či dokonce kárající rétoriku.

Další fázi lze nazvat „vymezení prostoru pro reflexi“: Sešli jsme se tady, abychom si popovídali o prožitém týdnu a o tom, co vám to přineslo, čím vás to novým obohatilo, co jste se napríklad naučili, cokoliv jiného, co vás napadne a co se se týká vás. Facilitátor tímto způsobem jasně ohraničuje téma, kterým je v tomto př́ípadě vzpomínání na prožité události v konkrétním časovém období. Důležitým faktem je způsob pohledu, jakým se na tyto zážitky mají účastníci dívat. Zkusme zůstat u toho, co mně to osobně přineslo. O podrobnější analýzu si rovněž ,ř́íká“ např. míra direktivity, s jakou facilitátor pracuje a jakou si může dovolit ve vztahu k cílům reflexe.

Další úsek můžeme označit jako „iniciaci komunikace podporující sebereflektivní procesy“. Lektor iniciuje proces vytváření významů z uplynulého týdne „otevírací neuzavřenou otázkou“. Tak pojd'me se ted'ka podívat na ten začátek a poohlídnout se po tom našem uplynulém týdnu. Je něco takového prvního, co vás k tomu napadá? Otázka směřuje do prostoru - jaká asociace se účastníkům vybaví, když si vzpomenou na uplynulý týden. Lektor hledá takovou „otevírací otázku“, na kterou se bude účastníkủm dobře odpovídat; tedy usiluje o nastartování interaktivního procesu výměny významů a sebereflexe účastníků. Asociativní pochody v tomto směru nevyžadují mnoho kognitivního úsilí a jsou dost často spontánní a bezprostřední. Cílem této fáze je stimulovat skrze komunikaci (otázky, intervence) sebereflektivní procesy jednotlivých účastníků.

V dalším stupni se dostáváme do klíčové fáze celého reflektivního procesu, kterou bychom mohli nazvat „usměrňování sebereflektivních procesư“. V ní se lektor již nesnaží podněcovat 
nové interakce, ale pouze ovlivňuje probíhající sebereflexi účastníků a snaží se iniciovat proces učení. K tomu využívá několik důležitých principư ${ }^{4}$ :

- Návaznost komunikace,

- usměrnění komunikačního obsahu reflexe,

- prohloubení uvědomění konkrétního tématu reflexe,

- práce s tichem ve skupině,

- ocenění a respekt.

Ve vztahu k lektorovu pojetí reflexe se jeví být důležitým fenoménem „návaznost komunikace“. To znamená, že se lektor snaží o to, aby každá odpověd’ účastníka pro něj byla podnětem pro novou otázku. Takový postoj je explicitně zachycen např. v této reakci lektora na odpověd' účastníka - Díky za to..., já se chytnu té poslední myšlenky, jestli můžu, protože vnímám, že to mám u spousty problémů podobně. Co myslíš, že by ti pomohlo v tom, do toho proniknout...?. Tento postoj je základním předpokladem komunikace během reflexe. Z této perspektivy je zajímavé, jak se na komunikaci dívají Maturana a Varela, kteří ji vidí jako strukturální návaznost jednoho slova na druhé, které udržuje lidský sociální systém (Šmausová, 1998, s. 31) ${ }^{5}$.

Další etapu vedení reflexe můžeme nazvat „,aplikační rovinou reflektivního procesu“. Co bude jinak, až se vrátíte do toho svého oddílu, jestli něco bude, co budete dělat jinak? [intonační důraz facilitátora byl na znění otázky]. V této chvíli facilitátor přesměrovává sebereflektivní proces od fáze „co mi to dalo“ $\mathrm{k}$ další fázi, která je již více orientovaná na budoucnost. Za zajímavé lze považovat, že účastníci hovoří o tom, co bude jinak, ale sám facilitátor přitom netuší, zda to tak skutečně bude. Jde svým způsobem o „fiktivní aplikaci“, která se pohybuje na rovině př́ání či vize. Ta je však důležitou, neoddělitelnou součástí změny, jak např́íklad ukazuje transteoretický model změny od Norcrosse a Prochasky (1999).

Poslední fází, kterou jsme v této sondě vypozorovali, je „uzavírání“ mající povahu určitého „kotvení“. Oukej, tak jo, já už vás nebudu nutit premýšlet, ono to všechno nějak doběhne a usadí se a každej to nějak pozná, jak to ovlivnilo jeho život. Rozhodně víme, že to nějak ovlivnilo náš život, takže vám přeji, abyste vše zvládli, až přijedete domu a zase nastartovali svoji činnost. V této ukázce lektor zřjejmě skrze obecnou formulaci potvrzuje přijetí určitých změn, které bylo možné $\mathrm{v}$ průběhu komunikace $\mathrm{s}$ účastníky zaznamenat, a zároveň nechává otevřenou cestu $\mathrm{k}$ dalším individuálním úvahám a reflexím. Nechává přitom na každém $\mathrm{z}$ účastníků, aby si k obecně formulovaným změnám dosadil vlastní význam.

\section{Shrnutí výsledků}

Výsledkem naší analýzy je identifikace poměrně zřetelně oddělených, přesto však vzájemně provázaných a na sebe navazujících fází reflexe, které obsahují specifické komunikační principy. Vedle těchto dílčích poznatků se zde vynořuje celá řada dalších témat souvisejících především s významy použitých výroků, jež mají na účinnost a efektivitu reflektivního procesu zásadní vliv. Jde např́íklad o způsob komunikace zaměřující se na upevnění vztahu, podporující

\footnotetext{
${ }^{4} \mathrm{Z}$ důvodu omezeného rozsahu textu, pojednáme pouze o jednom $\mathrm{z}$ principů.

${ }^{5} \mathrm{~S}$ fenoménem návaznosti interakce souvisí rekonstrukce významů, která je, jak se ukázalo, velmi zajímavá. Př́i vzájemné interakci dochází k posunům jednotlivých významů slov, která byla řečena. Nebo si dokonce účastník myslí, že tyto slova někdo použil a přitom to byl on sám, kdo je použil jako první, vysvětlení by mohla nabízet konstruktivistická teorie významu.
} 
myšlení účastníků, ale také o ironii, lektorovo hodnocení, míru jeho direktivity, apod. Těm jsme totiž, přestože je bylo možné v nahrávce zaznamenat, nevěnovali v tomto textu pozornost.

V kontextu celé empirické sondy se jeví jako nejvíce problematická otázka průběhu učícího se procesu jednotlivých účastníků, tedy zkoumání takových intervencí lektora, které skutečně vedou k reflexi a učení. Ty jsou z metodologického hlediska jen obtížně uchopitelné, a proto právě metodologie zkoumání reflektivních procesů zůstává výzvou nejen pro nás, ale bezesporu i celou řadu jiných výzkumných týmů.

\section{Literatura}

Argyris, C., \& Schön, D. (1974). Theory in practice: Increasing professional effectiveness. San Francisco: Jossey Bass.

Bateson, G. (1972). Steps to an ecology of mind. San Francisco: Chandler.

Boud, D., Keogh, R., \& Walker, D. (Eds.). (1985). Reflection: Turning experience into learning. New York: Kogan Page.

Dewey, J. (1938). Experience and education. New York: Collier Books.

Gibbs, G. (1988). Learning by doing: A Guide to teaching and learning methods. Oxford: Further Education Unit.

Jarvis, P. (1995). Adult and continuing education: Theory and practice. London: Routledge.

Kolb, D. A. (1984). Experiential learning: Experience as the source of learning and development. New Jersey: Prentice Hall.

Kolb. D. A., \& Fry, R. (1975). Toward an applied theory of experiential learning. In C. Cooper (Ed.), Theories of group process. London: John Wiley.

Lewin, K. (1946). Action research \& minority problems. Journal of Social Issues, 2(4), 34-46.

Mezirow, J. (1990). Fostering critical reflection in adulthood: A guide to transformative and emancipatory learning. San Francisco: Jossey-Bass.

Nehyba, J. (2011). Zkušenostně reflektivní učení a komfortní zóna. Pedagogická orientace, 21(3), 305321.

Priest, S., \& Gass, M. A. (2005). Effective leadership in adventure programming. Champaign: Human Kinetics.

Prochaska, J., \& Norcross, J. C. (1999). Psychoterapeutické systémy: průřez teoriemi. Praha: Grada.

Schön, D. A. (2003). The reflective practitioner: how professionals think in action. Aldershot: Ashgate.

Strauss, A., \& Corbinová, J. (1999). Základy kvalitativniho výzkumu: postupy a techniky metody zakotvené teorie. Boskovice: Albert.

Šmausová, G. (1998). Život je poznání. In B. Fajkus \& J. Polák (Eds.), Brněnské přednášky (pp. 21-34). Brno: MU.

Thompson, S. (2008). The critically reflective practitioner. New York: Palgrave Macmillan.

\section{Kontakt}

Mgr. Jan Nehyba

Mgr. Jan Kolár

MgA. Martin Hak

Masarykova univerzita

Filozofická fakulta, Ústav pedagogických věd

Akademické centrum osobnostního rozvoje (ACOR)

A. Nováka 1, 60200 Brno

e-mail: nehyba@phil.muni.cz

jankolar@phil.muni.cz

hak@phil.muni.cz 


\section{Bibliografické údaje}

Nehyba, J., Koláŕ, J., \& Hak, M. (2011). Reflexe a její podoba v procesu učení a osobnostně sociálním rozvoji. In T. Janík, P. Knecht, \& S. Šebestová (Eds.), Smíšený design v pedagogickém výzkumu: Sbornik př́spěvků z 19. výroční konference České asociace pedagogického výzkumu (s. 356-361). Brno: Masarykova univerzita.

Dostupné z: http://www.ped.muni.cz/capv2011/sbornikprispevku/nehybakolarhak.pdf doi: 10.5817/PdF.P210-CAPV-2012-42 